Thyroid

\title{
Effect of hypothyroidism on pancreatic $\beta$-cell mass and circulating insulin concentration in ovine fetuses
}

Shelley Harris ${ }^{1}$, Miles J De Blasio², FB Peter Wooding ${ }^{2}$, Abigail L Fowden², David Meredith ${ }^{1}$ and Alison J Forhead ${ }^{1,2}$

1'Department of Biological and Medical Sciences, Oxford Brookes University, Oxford, OX3 OBP, UK ${ }^{2}$ Department of Physiology, Development and Neuroscience, University of Cambridge, Cambridge, CB2 3EG, UK

Thyroid hormones are important regulators of fetal growth, although their mechanism of action remains unclear. This study investigated the effect of hypothyroidism on pancreatic $\beta$-cell development in fetal sheep.

All procedures were carried out under the UK Animals (Scientific Procedures) Act 1986. Under general anaesthesia between 105-110 days of gestation (d; term 145d), one twin fetus was thyroidectomised (TX), while the other was sham-operated as a control ( $n=19$ ewes). After maternal euthanasia, umbilical arterial blood was taken from both fetuses at either $129 d$ or $143 d(n=38)$. After fetal euthanasia, fetuses were weighed, measured and tissues collected. The whole fetal pancreas was weighed, fixed in $4 \%$ paraformaldehyde and embedded in paraffin wax. Pancreatic $\beta$-cells were identified immunohistochemically with an insulin antibody and their mass was calculated using the Cavalieri estimator (Visiopharm, Denmark). Plasma insulin, triiodothyronine $\left(T_{3}\right)$ and thyroxine $\left(T_{4}\right)$ concentrations were measured by ELISA or RIA. Data (mean \pm SEM) were assessed by two-way ANOVA followed by Tukey's post hoc test.

In TX fetuses, plasma $T_{3}$ and $T_{4}$ concentrations were at the lower limit of assay detection ( $T_{3}$, $6.7 \mathrm{pg} / \mathrm{ml} ; \mathrm{T}_{4}, 7.6 \mathrm{ng} / \mathrm{ml}$ ) at both ages. There were no differences in absolute body or pancreas weight between TX and sham fetuses at either age. At 143d, limb lengths, lungs, heart, stomach and small intestine of TX fetuses were growth retarded, while the kidneys and perirenal adipose tissue were significantly enlarged, compared with sham fetuses $(p<0.05)$.

Plasma insulin levels were significantly higher in TX fetuses at both $129 \mathrm{~d}$ (sham: $92 \pm 60 \mathrm{ng} / \mathrm{L}$; TX: $129 \pm 33 n g / L ; p<0.05$ ) and 143d (sham: $56 \pm 10 \mathrm{ng} / \mathrm{L} ;$ TX: $168 \pm 24 \mathrm{ng} / \mathrm{L} ; p<0.05$ ). Relative $\beta$-cell mass to body weight was significantly greater in TX fetuses at both $129 \mathrm{~d}$ (sham: $47 \pm 4 \mathrm{mg} / \mathrm{kg}$; TX: $79 \pm 6 \mathrm{mg} / \mathrm{kg}$; $p<0.05$ ) and $143 \mathrm{~d}$ (sham: $46 \pm 7 \mathrm{mg} / \mathrm{kg} ; \mathrm{TX}: 75 \pm 10 \mathrm{mg} / \mathrm{kg} ; \mathrm{p}<0.05)$. The results indicate that the thyroid hormone have an important role in the growth and development of fetal pancreatic islets.

Funded by the BBSRC and Nigel Groome PhD studentship. 